\title{
Pharmaceuticals and personal care products' (PPCPs) impact on enriched nitrifying cultures
}

\author{
Carla Lopez $^{1} \cdot$ Mac-Anthony Nnorom ${ }^{1} \cdot$ Yiu Fai Tsang ${ }^{2} \cdot$ Charles W. Knapp $^{1} \mathbb{C}$
}

Received: 8 April 2021 / Accepted: 31 May 2021

(C) The Author(s) 2021

\begin{abstract}
The impact of pharmaceutical and personal care products (PPCPs) on the performance of biological wastewater treatment plants (WWTPs) has been widely studied using whole-community approaches. These contaminants affect the capacity of microbial communities to transform nutrients; however, most have neither honed their examination on the nitrifying communities directly nor considered the impact on individual populations. In this study, six PPCPs commonly found in WWTPs, including a stimulant (caffeine), an antimicrobial agent (triclosan), an insect repellent ingredient ( $N, N$-diethyl-m-toluamide (DEET)) and antibiotics (ampicillin, colistin and ofloxacin), were selected to assess their short-term toxic effect on enriched nitrifying cultures: Nitrosomonas sp. and Nitrobacter sp. The results showed that triclosan exhibited the greatest inhibition on nitrification with $\mathrm{EC}_{50}$ of $89.1 \mu \mathrm{g} \mathrm{L}^{-1}$. From the selected antibiotics, colistin significantly affected the overall nitrification with the lowest $\mathrm{EC}_{50}$ of $1 \mathrm{mg} \mathrm{L}^{-1}$, and a more pronounced inhibitory effect on ammonia-oxidizing bacteria (AOB) compared to nitrite-oxidizing bacteria (NOB). The $\mathrm{EC}_{50}$ of ampicillin and ofloxacin was 23.7 and $12.7 \mathrm{mg} \mathrm{L}^{-1}$, respectively. Additionally, experimental data suggested that nitrifying bacteria were insensitive to the presence of caffeine. In the case of DEET, moderate inhibition of nitrification $(<40 \%)$ was observed at $10 \mathrm{mg} \mathrm{L}^{-1}$. These findings contribute to the understanding of the response of nitrifying communities in presence of PPCPs, which play an essential role in biological nitrification in WWTPs. Knowing specific community responses helps develop mitigation measures to improve system resilience.
\end{abstract}

Keywords PPCPs $\cdot$ Nitrifying bacteria $\cdot$ Nitrification inhibition $\cdot$ Acute toxicity $\cdot$ Nitrogen removal

\section{Introduction}

Recently, the widespread presence of pharmaceutical and personal care products (PPCPs) in the environment has drawn the attention of the research community due to the potential adverse effects on ecosystems and human health (Kümmerer 2009; Tran et al. 2018). Studies on the occurrence and fate

Responsible Editor: Robert Duran

Yiu Fai Tsang

tsangyf@eduhk.hk

Charles W. Knapp

charles.knapp@strath.ac.uk

1 Centre for Water, Environment, Sustainability \& Public Health, Department of Civil \& Environmental Engineering, University of Strathclyde, Glasgow G1 1XJ, UK

2 Department of Science and Environmental Studies, The Education University of Hong Kong, Tai Po, New Territories 999077, Hong Kong of PPCPs have shown that stimulants, antimicrobial agents, repellents and antibiotics have frequently been detected in aquatic systems and engineered facilities such as wastewater treatment plants (WWTPs). These compounds, representing a wide range of human consumption products disposed and excreted into the sewage systems, pass through WWTPs and are discharged into the water bodies (Balakrishna et al. 2017; Yang et al. 2017).

Among the PPCPs, caffeine (CF) is one of the most abundant chemicals in WWTP samples, and its concentrations range from a few $n g \mathrm{~L}^{-1}$ to $\mu \mathrm{g} \mathrm{L}^{-1}$ (Luo et al. 2014; Tran et al. 2014; Balakrishna et al. 2017; Paíga et al. 2019). CF is an organic stimulant compound that is commonly added to beverages and other products. Although the literature shows that CF is highly biodegradable in biological WWTPs with removal efficiencies $>80 \%$ (Sui et al. 2010; Dai et al. 2014; Tran et al. 2018), the increase in CF consumption worldwide may lead to higher amounts discharged to the water bodies, increasing the risk of exposure in the ecosystems (Quadra et al. 2020). 
Other substances frequently detected in WWTPs include the antimicrobial agent triclosan (TCS) and the active ingredient of insect repellent $N, N$-diethyl- $m$-toluamide (DEET) (Liu and Wong 2013; Yang et al. 2017; Juksu et al. 2019). TCS concentrations have been reported in different influents of WWTPs worldwide, and the values are as high as $0.47 \mu \mathrm{g}$ $\mathrm{L}^{-1}$ in China (Zheng et al. 2020), 86.1 $\mathrm{gg} \mathrm{L}^{-1}$ in the USA (Kumar et al. 2010) and $17.6 \mu \mathrm{g} \mathrm{L}^{-1}$ in South Africa (Lehutso et al. 2017). In the case of DEET, the concentrations observed in WWTPs range from a few $\mathrm{n} \mathrm{L}^{-1}$ up to peak values as high as $15.8 \mu \mathrm{g} \mathrm{L}^{-1}$ in Europe (Merel and Snyder 2016) and $42.3 \mu \mathrm{g} \mathrm{L}^{-1}$ in the USA during the summer season (Mohapatra et al. 2016). Due to the variable removal efficiencies in WWTPs (Luo et al. 2014), TCS and DEET can be found in different environmental matrices, such as treated effluent, surface waters, waste sludge and sediments (Ramaswamy et al. 2011; Dai et al. 2014; Zhao et al. 2010; Dsikowitzky et al. 2020).

One of the most concerning pharmaceuticals in WWTPS are antibiotic residues. These compounds treat different infectious diseases and their disposal into the environment toxicologically impacts non-target microorganisms in the ecosystems, develops antimicrobial resistance, and contaminates soils and water bodies (Kümmerer 2009). Studies have shown that many antibiotic compounds have often been excreted in urine and/or faeces, cleansed off bodies or even disposed directly to sewers with minimal change after their administration (Marx et al. 2015); they are frequently detected in influent and effluent on WWTPs, suggesting a degree of persistence through treatment plants (Tran et al. 2016; Mutiyar and Mittal 2014; Leung et al. 2012). Survey-based studies indicate that conventional WWTPs generally do not efficiently remove antibiotics (Paíga et al. 2019)

According to the review of antimicrobial consumption by Robertson et al. (2019), $\beta$-lactams were the most commonly prescribed antibiotics worldwide in 2015. In this antibiotic class, ampicillin (AMP) has been widely used in human medicine and is considered highly degradable due to its unstable $\beta$-lactam ring structure (Watkinson et al. 2007). However, the chemical transformation of $\beta$-lactam antibiotics could vary depending on the matrix conditions (Mitchell et al. 2014), where in some cases AMP could still be detected even in treated effluent from WWTPs (Mutiyar and Mittal 2014).

Other predominant antibiotics in WWTPs are fluoroquinolones (Tran et al. 2018). Within this group, ofloxacin (OFX) is a second-generation antibiotic applied to treat urinary tract infections (King et al. 2000). Although restricted by the WHO (Robertson et al. 2019), the presence of OFX continues in raw sewage and effluent in WWTPs (Brown et al. 2006; Dinh et al. 2017), reaching concentrations of $7.9 \mu \mathrm{g} \mathrm{L}^{-1}$ in Asia (Leung et al. 2012; Minh et al. 2009) and $8.6 \mu \mathrm{g} \mathrm{L}^{-1}$ in Europe (Dinh et al. 2017).
Another source of antibiotics in WWTPs are veterinary medicines (Kemper 2008). Under this application, colistin (CST) is a polymyxin antibiotic that is widely used in animal farms to treat Gram-negative infections (Liu et al. 2016; Kempf et al. 2016) and it has re-emerged as a 'last-resort' antibiotic to target multidrug-resistant infections (Dagla et al. 2019). The occurrence of CST remains limited given that analytical methods for its quantification remain under development for environmental samples (Song et al. 2020). However, the detection of CST on biological matrices (Dagla et al. 2019) and the presence of a CST resistome in bacteria from WWTPs (Hembach et al. 2017) suggest that CST may pose a risk to microbial communities.

The presence of PPCPs in WWTPs is crucial because they can adversely affect biological treatment processes; these systems rely on microbial communities to transform nutrients, such as nitrogen, to prevent aquatic eutrophication (Xiao et al. 2015). For example, biological nitrification, which is part of the nitrification-denitrification reaction sequence in WWTPs, involves a two-step process carried out by two autotrophic microorganisms, namely ammonia-oxidising bacteria $(\mathrm{AOB})$ and nitrite-oxidising bacteria (NOB) (Koops and Pommerening-Röser 2001). Moreover, the performance of AOB-NOB communities can be disrupted due to their fragile mutualism (Graham et al. 2007; Knapp and Graham 2007), low phylogenetic diversity, slow growth characteristics and sensitivity to toxic chemicals (Li et al. 2016).

The role of nitrifiers on biological nitrogen removal is a critical process in wastewater treatment and their response against toxic chemicals is of great concern for the stability and performance of WWTPs (Xiao et al. 2015). The adverse effect of pharmaceuticals on nitrifying communities has been reported in wide range of conditions including short- and long-term exposure at different concentrations. The findings have shown that these compounds can decrease nitrification rates, leading to poor ammonium removal efficiency and disruption of the $\mathrm{AOB}-\mathrm{NOB}$ mutual cooperation, producing partial nitrification with nitrite accumulation. Other effects observed are the inhibition of enzymatic activities of $\mathrm{AOB}-$ NOB species with reduction of ammonia-monooxygenase (AMO) and nitrite-oxidoreductase (NOR) enzymes and the variation of the bacterial community composition, shifting their richness and diversity (Kong et al. 2017; Yu et al. 2019; Li et al. 2020; Zhang et al. 2020).

Despite published data, toxicity assessments of the common PPCPs on AOB-NOB communities are limited and even unavailable in some cases. Most of the studies found in literature were performed with high concentrations of activated sludge as the biomass source, where the presence of more diverse microbial populations and high solid content could lead to varied inhibition results on nitrifying species (Lakshminarasimman et al. 2018; Armstrong et al. 2019; Zhang et al. 2020). 
This study investigated the effect of selected PPCPs, including a stimulant (CF), personal care products (DEET and TCS) and antibiotics (AMP, OFX and CST), on an enriched nitrifying community. Batch reactors were employed to assess the acute toxicity of these substances, where changes of ammonium, nitrite and nitrate concentrations were measured to determine nitrification inhibition. Enriched nitrifying bacteria were selected as the inoculum with efforts to increase nitrification activity, control the presence of heterotrophic bacteria and remove solids from activated sludge, which could alter nutrients, transform the toxic substances and interfere with the interaction of nitrifying bacteria with the test substance (Zhang et al. 2020). The findings obtained in this study expand our understanding of the short-term effects of PPCP exposure on nitrifying bacteria, which could importantly prevent the failure of biological nitrogen removal systems in WWTPs.

\section{Materials and methods}

\section{Cultivation of nitrifying bacteria}

Activated sludge, collected from a WWTP in Scotland, was used as the source of nitrifying bacteria. The enrichment of nitrifiers was carried out in batch cultures according to the procedure described by Bollmann et al. (2011) and Radniecki and Lauchnor (2011). The nutrient media were modified from Bollmann et al. (2011) with the following final chemical composition $\left(\mathrm{g} \mathrm{L}^{-1}\right): 0.5\left(\mathrm{NH}_{4}\right)_{2} \mathrm{SO}_{4}$ as an inorganic nitrogen source; $0.585 \mathrm{NaCl}, 0.054 \mathrm{KH}_{2} \mathrm{PO}_{4}, 0.147$ $\mathrm{CaCl}_{2} \cdot \mathrm{H}_{2} \mathrm{O}, 0.075 \mathrm{KCl}, 0.049 \mathrm{MgSO}_{4} \cdot 7 \mathrm{H}_{2} \mathrm{O}$ and 0.5 $\mathrm{NaHCO}_{3}$ as the inorganic carbon source; 7.21 HEPES as a buffer and $1 \mathrm{~mL}$ of trace elements solution from Schmidt and Belser (1994). After autoclaving at $121^{\circ} \mathrm{C}$ for $20 \mathrm{~min}$, the $\mathrm{pH}$ media was adjusted to $7.6 \pm 0.2$ ( $\mathrm{pH} /$ conductivity meter; Mettler Toledo, MPC 227, Switzerland) with $10 \mathrm{M} \mathrm{NaOH}$ (sodium hydroxide solution; Fisher Scientific).

In the first stage of enrichment, $1 \mathrm{~g}$ (wet mass) of activated sludge was inoculated into 100-mL Erlenmeyer flasks with media, followed by a series of repeated transfers in fresh media to promote the growth of nitrifiers as explained by Bollmann et al. (2011). The procedure aimed to reduce the activated sludge flocs and particles that could interact or degrade the test substance, and minimise nitrogen assimilation by heterotrophic bacteria that could affect nitrification measurements (ISO 9509 2006; Chen et al. 2014). This process continued for 3 months, where $\mathrm{AOB} / \mathrm{NOB}$ activities in each culture flask were evaluated through visible observation of ammonium disappearance using Nessler reagent $(\mathrm{HACH}$, Germany), and spots test strips for nitrite and nitrate detection (AquaChek; HACH, Germany).

Once the cultures presented stable activity, the bacterial broth was transferred to 2 -L glass bottles (three lab-scale reactors in total) for further enrichment and provide sufficient inoculum for the toxicity tests. The air was supplied with an air pump (HDOM, Model HD-603; Shenzhen Hidom Electric Co., Ltd.) filtered with a $0.2-\mu \mathrm{m}$ sterilising-grade filter (Aervent ${ }^{\mathrm{TM}}$ ) to maintain the dissolved oxygen (DO) above $4 \mathrm{mg} \mathrm{L}{ }^{-1}$ (DO meter; Eutech Instruments Pte Ltd., DO 6+ $\mathrm{DO} /$ Temp, Singapore). The reactors were operated at room temperature $\left(20-27^{\circ} \mathrm{C}\right)$ and were periodically provided with $\left(\mathrm{NH}_{4}\right)_{2} \mathrm{SO}_{4}$ solution as substrate and $\mathrm{NaOH}$ solution (sodium hydroxide solution $10 \mathrm{M}$; Fisher Scientific) to maintain optimum $\mathrm{pH}$ (7.6-7.8). The reactors' working volume was $1.7 \mathrm{~L}$ and every 2 weeks, $1.2 \mathrm{~L}$ of supernatant was removed and replaced with the same volume of fresh nutrient medium to prevent excessive accumulation of by-products.

Batch toxicity assays

We consulted the ISO 9509 (2006) protocols for the experiment design; it evaluates the exclusive capacity of nitrifiers to transform inorganic nitrogen into oxidation species, and it represents a more sensitive approach (Stasinakis et al. 2008; Yuan et al. 2019; Brandt et al. 2015). Study duration was extended up to 2-3 days in contrast to the few hours proposed by the protocol ISO 9509 (2006), to account for the relatively slow-growing populations (Radniecki and Lauchnor 2011). For each assay, the incubation was finalised before ammonium concentrations reached zero to avoid substrate limitation.

An enriched nitrifying community was selected; it remains representative of the AOB-NOB communities present in WWTPs (Li et al. 2016) but minimises interference of ammonia assimilation by excessive heterotrophic bacteria. The experimental conditions of the batch assays for the six PPCPs are summarised in Table 1. The tests were performed individually in the following order: CF, AMP, TCS, DEET, CST and OFX. Batch cultures were undertaken in 500-mL glass bottles with 300-mL working volume. Each treatment was inoculated with $50 \mathrm{~mL}$ (equivalent to $337 \pm 19 \mathrm{mg} \mathrm{VSS} \mathrm{L}^{-1}$ ) of bacterial suspension harvested from the 2-L (enriched stock) reactors. Due to the slow growth of nitrifying bacteria, the first three tests (CF, AMP and TCS) were run in duplicate to cover a broad range of concentrations. Eventually, sufficient quantities of biomass stock were generated to run the experiments in triplicates for the last three toxicants (DEET, CST and OFX). Similar nutrient media were prepared for the assays with lower initial ammonium concentration $\left(<56 \mathrm{mg} \mathrm{L}^{-1} \mathrm{NH}_{4}{ }^{+}-\mathrm{N}\right)$ as recommended by ISO 9509 (2006).

Before inoculation, the biomass was subjected to a cleaning procedure that involved centrifugation, settling, decanting and resuspension to remove any remaining traces of oxidised products and minimise organic material, and ensure sufficient buffering capacity during the assays (Moussa et al. 2003; Salem et al. 2006). Initially, the nitrifying biomass used for the first three PPCPs (i.e. CF, AMP and TCS) were centrifuged at $10,000 \times g$ for $35 \mathrm{~min}$, settled (20 min), decanted and refilled with new test media; this procedure was repeated twice. It was observed that 
Table 1 Initial operating conditions for the short-term batch assays

\begin{tabular}{|c|c|c|c|c|c|c|}
\hline Variable & $\mathrm{CF}$ & AMP & TCS & DEET & CST & OFX \\
\hline $\mathrm{NH}_{4}{ }^{+}-\mathrm{N}\left(\mathrm{mg} \mathrm{L}^{-1}\right)^{*}$ & $53.3 \pm 0.6$ & $53.2 \pm 0.6$ & $53.1 \pm 0.5$ & $50.3 \pm 0.5$ & $50.6 \pm 0.7$ & $49.7 \pm 0.6$ \\
\hline $\mathrm{NO}_{2}{ }^{-}-\mathrm{N}\left(\mathrm{mg} \mathrm{L}^{-1}\right)^{*}$ & $1.0 \pm 0.1$ & $1.0 \pm 0.1$ & $0.7 \pm 0.1$ & $1.5 \pm 0.2$ & $0.7 \pm 0.2$ & $1.6 \pm 0.2$ \\
\hline $\mathrm{NO}_{3}{ }^{-}-\mathrm{N}\left(\mathrm{mg} \mathrm{L}^{-1}\right)^{*}$ & $0.8 \pm 0.1$ & $0.5 \pm 0.2$ & $0.5 \pm 0.1$ & $3.7 \pm 0.2$ & $4.6 \pm 0.5$ & $9.4 \pm 0.4$ \\
\hline $\mathrm{pH}$ range & $7.4-7.7$ & 7.8 & $7.7-7.8$ & $7.6-7.8$ & 7.7 & $7.4-7.7$ \\
\hline Temperature $\left({ }^{\circ} \mathrm{C}\right)$ & $20-22$ & $20-22$ & $22-27$ & $20.5-22$ & $21.5-22$ & $21-22$ \\
\hline $\mathrm{DO}\left(\mathrm{mg} \mathrm{L}^{-1}\right)$ & $>5$ & $>5$ & $>5$ & $>5$ & $>5$ & $>5$ \\
\hline Protein $\left(\mathrm{mg} \mathrm{L}^{-1}\right)$ & 4.7 & 4.7 & 6.3 & 6.3 & 6.3 & 9.0 \\
\hline Replicates & Duplicates & Duplicates & Duplicates & Triplicates & Triplicates & Triplicates \\
\hline Volume (mL) & 300 & 300 & 300 & 300 & 300 & 300 \\
\hline Duration (h) & 73 & 68 & 34 & 43 & 74 & 33 \\
\hline
\end{tabular}

*Nitrogen values are represented by mean \pm standard deviations longer centrifugation and settling time of the biomass led to significant nitrite accumulation in the batch assays; thus, the washing procedure for the last three PPCPs (i.e. DEET, CST and OFX) was optimised by halving processing times.

During experimentation, cultures were supplied with humidified air via aeration stones at the bottom of each bottle to maintain DO above $4 \mathrm{mg} \mathrm{L}^{-1}$. $\mathrm{pH}$ was measured at the beginning and end of the incubation period. Temperature was recorded using a USB Temperature Data Logger (Lec, EasyLog USB version 7.6.0.0; Lascar Electronics Ltd.).

Biomass concentrations were estimated by their protein content using the Micro BCA Protein Assay kit (Thermo Scientific, USA), following their procedure. Volatile suspended solids (VSS) concentrations were determined according to Standard Methods (APHA 1998). All batch assays (per test substance) were inoculated with the same amount of biomass and substrate concentration, and the protein concentrations were $6.2 \pm 1.6 \mathrm{mg} \mathrm{L}^{-1}$ (equivalent to $71 \pm 5 \mathrm{mg} \mathrm{VSS}$ $\mathrm{L}^{-1}$ ); changes in microbial protein content between the beginning and end of the incubation period were negligible.

As an additional treatment 'control' and to compare activity responses of the consortium, reference inhibitor allylthiourea (ATU) was used at $0.3 \mathrm{mg} \mathrm{L}^{-1}$, a selective ammoniamonooxygenase inhibitor of AOB populations (Gwak et al. 2020 ) and nitrification. AOB are considered the limiting step of nitrification (ISO 9509 2006). This was used to verify whether ammonium disappearance was resultant of autotrophic nitrification.

Samples were collected during the incubation period, filtered with a $0.45-\mu \mathrm{m}$ cellulose filter and preserved following protocol BSI EN ISO 5667-3 (2018) for analysis of ammonium, nitrite and nitrate. Unfiltered samples were collected for DNA and protein test and preserved at $-80^{\circ} \mathrm{C}$ until analysis.

The nitrification activity in the batch assays was measured by monitoring nitrogen species over time. The oxidised nitrogen $\left(\mathrm{NO}_{\mathrm{X}}-\mathrm{N}\right)$, the sum of $\mathrm{NO}_{2}{ }^{-}-\mathrm{N}$ and $\mathrm{NO}_{3}{ }^{-}-\mathrm{N}$ concentrations, obtained for the different treatments were used to calculate the inhibition percentages in Eq. (1). The values correspond to the measurements at the end of each experiment and reported as the mean value of triplicate or duplicate assays. These percentages were plotted as a function of the toxicant concentrations.

$\%$ Inhibition $=\frac{\left(N O_{X} \text { control }-N O_{X} \text { test }\right)}{N O_{X} \text { control }} \times 100$

$N O_{X}$ test and $N O_{X \text { control }}$ represented the concentrations of oxidised nitrogen $\left(\mathrm{mg}-\mathrm{N} \mathrm{L}^{-1}\right)$ in each batch reactor with the toxic substance, and the 'control' absent of the toxicant. All concentrations were adjusted by subtracting the initial concentration of nitrite or nitrate to record the variation of the oxidation species over the incubation period.

The substance concentration that decreases nitrification activity in comparison to the controls by $50 \%$ is defined as $50 \%$ effective concentration $\left(\mathrm{EC}_{50}\right)$. This value was estimated by interpolating the graph of inhibition percentage (Eq. (1)) against the log-transformed toxicant concentration. The profile was adjusted to a linear or polynomial model, considering the best fit with a coefficient of determination $\left(R^{2}\right)>0.96$ (ISO 9509 2006).

Test substances

Caffeine ( $>95 \%$ purity), irgasan or triclosan ( $\geq 97 \%$ purity), $N, N$-diethyl-3-methylbenzamide or DEET ( $>97 \%$ purity), ampicillin (ready-made solution, $100 \mathrm{mg} \mathrm{mL}^{-1}$ ), ofloxacin ( $\geq 99 \%$ purity) and colistin sulphate salt $\left(\geq 15,000 \mathrm{U} \mathrm{mg}^{-1}\right)$ were purchased from Sigma Aldrich. The range of concentrations selected for the batch assays is presented in Table 2 . These concentrations were chosen to include a range commonly found in WWTPs based on the values reported in the literature for either WWTPs or previous inhibition studies (see Table 2); however, higher concentrations were included to evaluate whether target compounds would produce any response to nitrification performance (Pasquini et al. 2013). 
Table 2 PPCP concentrations tested in batch reactors

\begin{tabular}{lllll}
\hline Class & Substance & CAS number & Concentrations $\left(\mathrm{mg} \mathrm{L}^{-1}\right)$ & Reference \\
\hline Stimulant & CF & $58-08-2$ & $0.025,0.115,1,10,40,90$ & (Gheorghe et al. 2016) \\
Antimicrobial & TCS & $3380-34-5$ & $0.01,0.1,0.3,0.5,1,2$ & (Roh et al. 2009) \\
Insect repellent & DEET & $134-62-3$ & $0.02,0.1,1,5,10$ & (Aronson et al. 2012) \\
Antibiotics & AMP & $69-52-3$ & $0.5,5,50,100,175,250$ & (Gomez et al. 1996) \\
& CST & $1264-72-8$ & $0.1,1,10,100,350$ & (Bressan et al. 2013) \\
& OFX & $82419-36-1$ & $0.01,0.1,1,5,10$ & (Dokianakis et al. 2004) \\
\hline
\end{tabular}

Stock solutions were prepared on the same day of the assay, and Milli-Q water was used for the antibiotics and CF. Because TCS and DEET have poor solubility in water, the solutions were prepared with dimethyl sulphoxide (DMSO) as solvent $(<0.1 \% \mathrm{v} / \mathrm{v})$, and similar concentrations of DMSO were maintained in all treatments.

The fate of the substances was not analysed, but it was considered in the assays; reported half-lives were $\mathrm{CF}$, a few hours (Dorival-García et al. 2013); OFX, $>4$ days (DorivalGarcía et al. 2013); DEET, days to weeks (Weeks et al. 2012; Lakshminarasimman et al. 2018); and partial biodegradation reported for TCS (Lakshminarasimman et al. 2018) and AMP (Ramírez Muñoz et al. 2020). Test bottles were covered with foil to prevent light exposure and possible photolysis (e.g. Bedoux et al. 2012); pH and temperature were balanced between microbial activity and compound stability (e.g. Mitchell et al. 2014; Li et al. 2003). Most previous studies used activated sludge with VSS quantities $10^{2}-10^{3}$ times higher than this study. Therefore, it is hoped that low biomass levels and autotrophic nature of the media in the assays minimised degradation of the tested chemicals.

Analytical methods

The concentrations of ammonium, nitrite and nitrate were determined through colorimetric analysis using KoneLab Aqua 30 (Thermo Scientific, Aquarem 300; Clinical Diagnostics Finland) according to the British Standard procedures BS ISO 15923-1 (2013). For the colorimetric analysis, pre-tests involved spiked controls to determine whether any interference by other compounds had any effect on assays. All the reagents were purchased from Thermo Fisher.

DNA extraction and 16S-rRNA gene sequencing and analysis

Four samples were tested to analyse their microbial community structure. Two were collected from the bioreactors at the beginning of the experiments ( $\mathrm{S} 1$ and $\mathrm{S} 2$ ) and the two other (S3 and S4) at the end of the testing period, after $\sim 8$ months of harvesting. All samples were stored at $-80{ }^{\circ} \mathrm{C}$ in 2-mL tubes prior to the analysis.

DNA were extracted from biomass samples collected from the reactors using a QIAGEN DNeasy® Blood \& Tissue Kit, according to the manufacturer's instructions. The DNA quantity was estimated using a Spectrophotometer Microplate Epoch (BioTek Instruments, Inc., USA) and data collection and analysis software Gen5 ${ }^{\mathrm{TM}}$ V1.11.5 (BioTek Instruments, Inc., USA).

DNA sequencing was performed at Glasgow Polyomics (Glasgow, UK) using Illumina MiSeq platform, targeting the 16S-rRNA operon for taxonomy, using recommended primers by RDP-II Pipeline (Maidak et al. 2001; https://rdp. cme.msu.edu); and further, bioinformatic identification of microbial community was performed with QIIME2 version 2021.2 (Bolyen et al. 2019), with similar data analysis detailed by Al Ali et al. (2020) (see Supplementary information).

\section{Results and discussion}

During the pre-experimental enrichment process, ammonium conversion to nitrite increased rapidly and low nitrate production was observed ( $0.3 \mathrm{mg} \mathrm{NO}{ }_{3}{ }^{-} \mathrm{N} / \mathrm{mg} \mathrm{NH}_{4}{ }^{+}-\mathrm{N}$ consumed), leading to nitrite build-up in the reactors. However, nitrite accumulation gradually decreased, reaching undetectable values after 2 months of operation. Subsequently, the reactors achieved a stable nitrification performance, maintaining an ammonium consumption rate between 11 and $20 \mathrm{mg} \mathrm{NH}_{4}{ }^{+}$ $\mathrm{N} / \mathrm{g}$ MLVSS $\mathrm{h}$ and a nitrate production yield of $0.95 \mathrm{mg}$ $\mathrm{NO}_{3}{ }^{-}-\mathrm{N} / \mathrm{mg} \mathrm{NH}_{4}{ }^{+}-\mathrm{N}$-i.e. $95 \%$ of ammonia disappearance was attributed to nitrification. These cultures were sustained in batch reactors and were the 'stock' for subsequent assays.

Microbial community

The taxonomic classification derived from the 16S rRNA gene sequencing and analysis is illustrated in Fig. S1 (Supplementary information). At phylum level, Proteobacteria were dominant in all analysed samples, accounting for $63-68 \%$ of the total bacterial population; followed by Bacteroidetes, 19 (S1-S2) to $30-32 \%$ (S3 and S4); Chlorobi, 10 to $0.4-3 \%$ (S3 and $\mathrm{S} 4$, respectively); and the remaining bacteria represented $<10 \%$ of sequences. These phylogenetic groups are representative of those in activated sludge (Johnston et al. 2019; Zhang et al. 2019) and enriched nitrifying cultures (Kapoor et al. 2016; Jeong and Bae 2021). 
The 16S-rRNA phylo-taxonomic analysis recognised Nitrosomonas sp. (AOB) and Nitrobacter sp. (NOB) in the enriched community (see Table S2, Supplementary information). The relative abundance of Nitrosomonas sp. increased from $5.2 \%$ at the beginning to $5.7 \%$ at the end. In terms of Nitrobacter sp., they ranged $0.1-0.8 \%$ of the total microbial population. Notably, no Nitrospira sp., another possible NOB, was found. While these bacteria are typically found in biological wastewater treatment systems, they tend to be more sensitive to environmental conditions (Graham et al. 2007; Knapp and Graham 2007). Further, the prevalence of Nitrobacter sp. over Nitrospira sp. exposed to higher nitrite levels has been demonstrated (Nogueira and Melo 2006; Nowka et al. 2015).

The final abundances of AOB and NOB species are contingent of the enrichment process; higher proportions of nitrifying bacteria could be grown with long periods of cultivation (Ye et al. 2011; Wang et al. 2019) and fully automatic controlled bioreactors (Yao et al. 2016). In comparison, here, the abundances of AOB ad NOB guilds were within the same order of magnitude to those with similar duration of enrichment (Stadler and Love 2016; Kwon et al. 2019; Jeong and Bae 2021). Additionally, nitrifying activity achieved complete removal of ammonium and nitrate production without nitrite accumulation over the period of enrichment.

Control cultures

All experimental treatments were inoculated with similar nitrifying consortia, wherein batch reactors absent of the toxicant were used as controls. Figure 1 shows the exemplary performance over time in the controls during the first (CF) and the last (OFX) assays; remaining information is presented in the Supplementary information. All controls achieved microbial nitrification, reducing $>90 \%$ of the initial ammonium concentration. Moreover, the increase in nitrite and nitrate levels indicated the activities of $\mathrm{AOB}$ and $\mathrm{NOB}$, respectively. However, a substantial amount of nitrite accumulated during the incubation, suggesting that the ammonium oxidation rate was higher than the nitrite oxidation rate. At the end of the experiment, nitrite levels were higher in the CF controls (Fig. 1a) than those in the OFX controls (Fig. 1b). This difference could be attributed to modification of culture-rinsing preparations between the two testing groups (as described in the "Materials and methods" section); neither culture was exposed to any contaminant ('controls'). This effect has been highlighted by other authors (Moussa et al. 2003), and the reduction of oxygen level in the washed biomass could possibly have a detrimental effect on NOB activity (Peng and Zhu 2006).

Experimental conditions were consistent between assays (Table 1). However, temperatures during TCS test were aberrantly $+5{ }^{\circ} \mathrm{C}$ (Table 1 ). While the change of temperature within this range can increase the activity of Nitrosomonas sp. (AOB species) and Nitrobacter sp. (NOB species) by 30 to
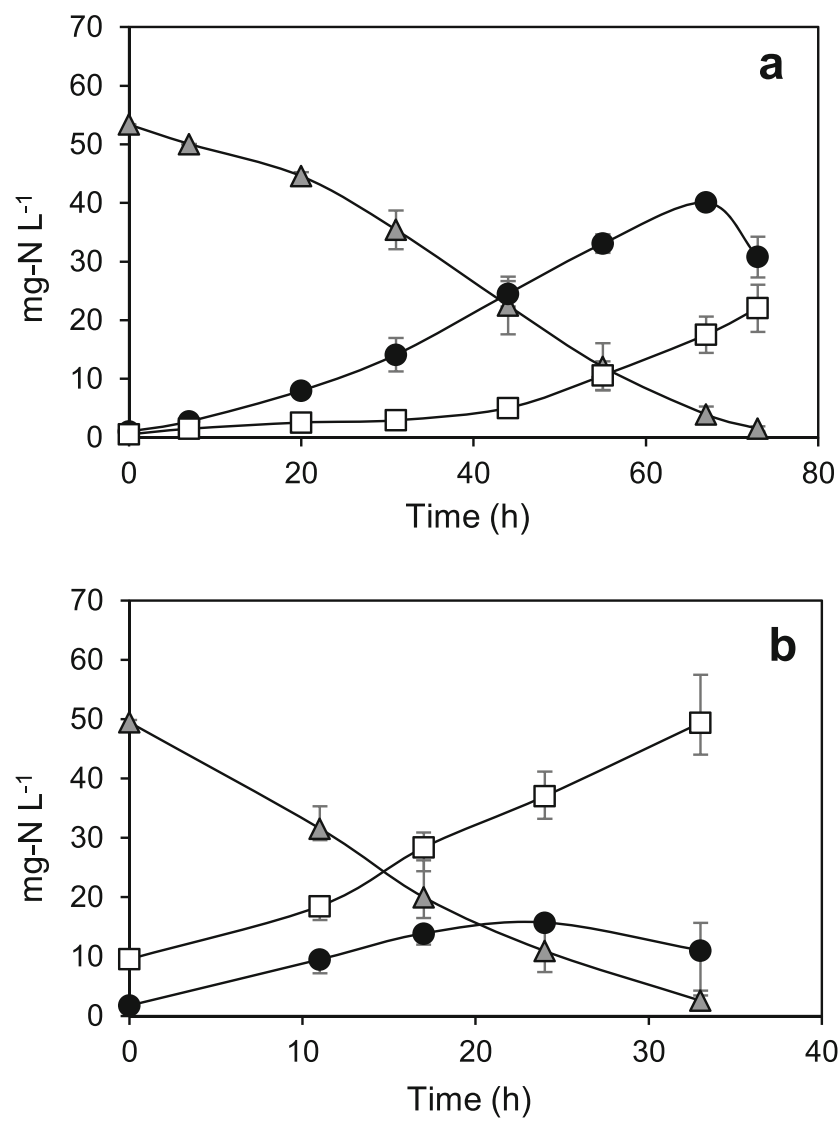

$\neg$ Ammonium $\longrightarrow$ - Nitrite $\quad \square-$ Nitrate

Fig. 1 Nitrifying control cultures during the a caffeine test and $\mathbf{b}$ ofloxacin test. Data points show average concentration \pm maximum and minimum values

40\% (Grunditz and Dalhammar 2001), it should be noted that all dose-response assays for each toxicant were conducted simultaneously and compared with controls to minimise collineating factors.

Mass balance of nitrogen based on ammonium consumption, nitrite consumption/production and nitrate production was monitored through the toxicological tests (see Table S1, Supplementary information). Accountability of ammonia transformation to its oxidised products was within $\pm 6 \%$ of expectation (mean $0.1 \%, \pm 2.6 \% \mathrm{SD}$ ). Besides the slight variations from the chemical analyses, some differences may be due to ammonia volatilisation or assimilation.

Effects of caffeine on nitrification activity

Nitrification activity was evaluated by monitoring the concentration of ammonium, and of the oxidation species nitrite and nitrate over time to assess the effects of CF on the nitrifying cultures. Figure 2 shows the nitrification performance of the batch cultures for the different $\mathrm{CF}$ concentrations (Table 2), including that of the control culture and the reference inhibitor ATU. At the end of the experiment, $97.4 \pm$ $0.65 \%$ of ammonium was consumed in all replicates and the total oxidised compounds (controls and batch reactors spiked 

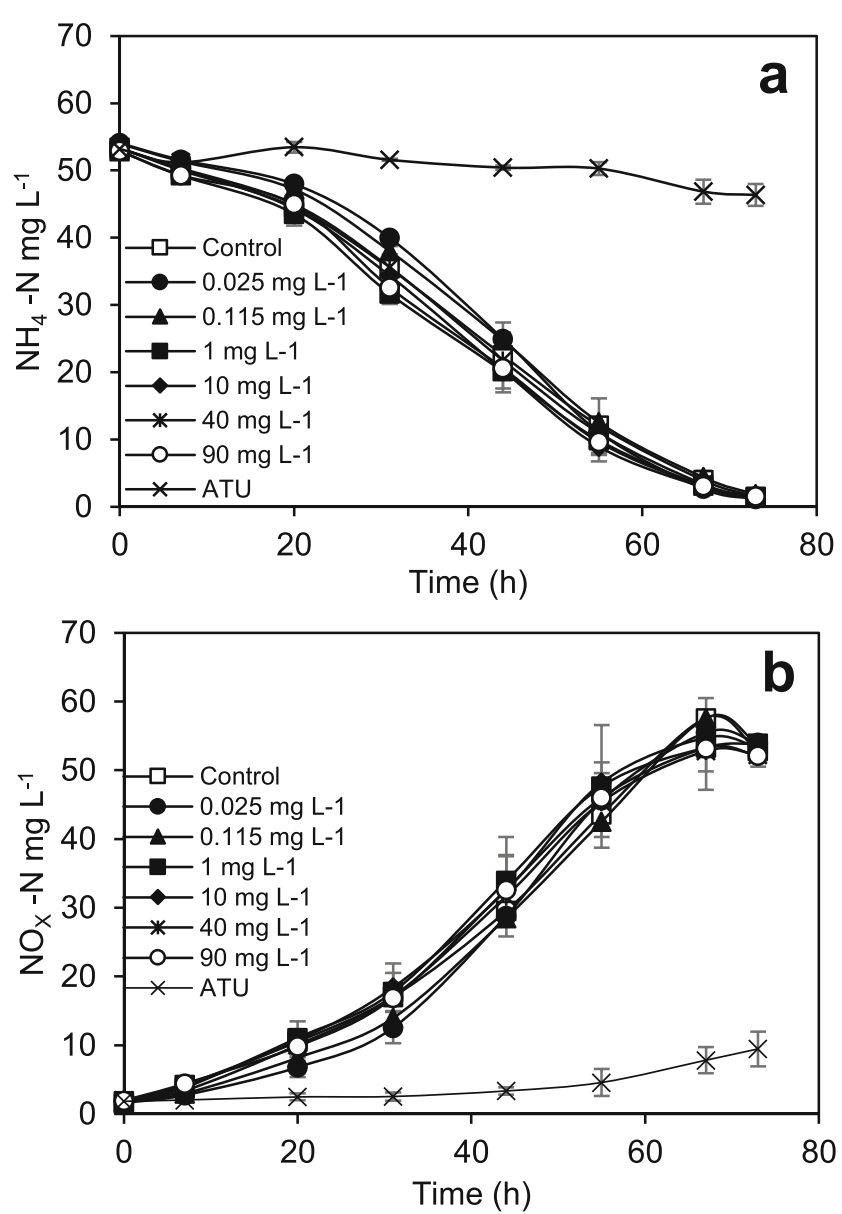

Fig. 2 Nitrification profiles of cultures in presence of $\mathrm{CF}$ at different concentrations: a $\mathrm{NH}_{4}{ }^{+}-\mathrm{N}$ and b $\mathrm{NOx}-\mathrm{N}\left(\mathrm{NO}_{2}^{-}+\mathrm{NO}_{3}^{-}\right)$. Data points show average concentration \pm maximum and minimum values

with $\mathrm{CF}$ ) were $51.4 \pm 1.0 \mathrm{mg} \mathrm{L}^{-1} \mathrm{NOx}-\mathrm{N}$ with a coefficient of variation less than $2 \%$.

There is scarce information about CF impacts on nitrification; He et al. (2018) suggested nitrification was not impacted during a CF-biodegradation experiment. However, CF can affect other bacteria (Gheorghe et al. 2016). In summary,

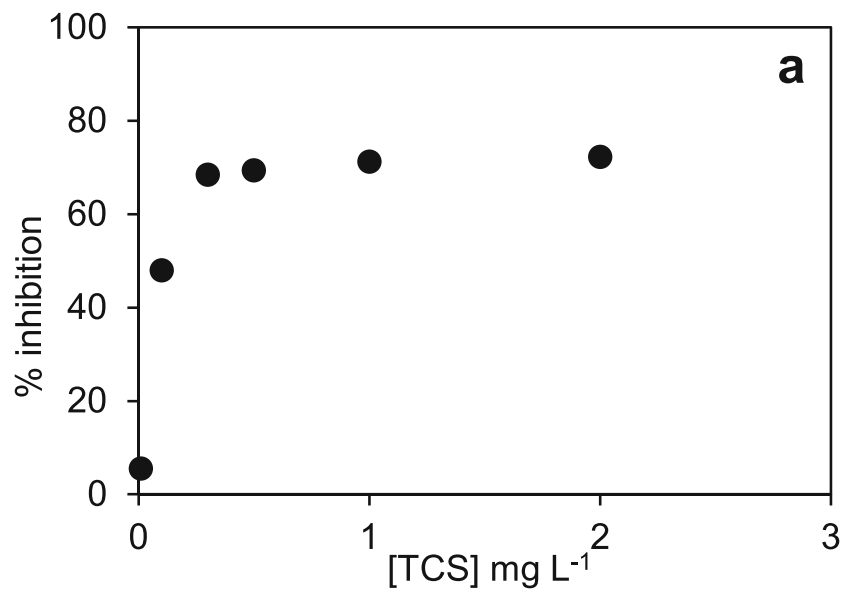

Fig. 3 Inhibition level at different concentrations of triclosan results indicated that $\mathrm{CF}$ did not considerably inhibit nitrification even at the highest concentration at $90 \mathrm{mg} \mathrm{L}^{-1}$; neither \% inhibition nor $\mathrm{EC}_{50}$ was calculated.

Effects of triclosan and DEET on nitrification activity

The inhibition (\%) at different TCS concentrations was estimated using Eq. (1), and the $\mathrm{EC}_{50}$ value was obtained from Fig. 3. There was no observable effect at the lowest concentration of $0.01 \mathrm{mg} \mathrm{L}^{-1}$ compared to the control treatments (Fig. 3a); however, a tenfold increase in TCS levels $(0.1 \mathrm{mg}$ $\mathrm{L}^{-1}$ ) inhibited nitrification by $>50 \%$. Furthermore, inhibition was $72.3 \%$ at the highest concentration $\left(2 \mathrm{mg} \mathrm{L}^{-1}\right)$. The $\mathrm{EC}_{50}$ value calculated for TCS was $89.1 \mu \mathrm{g} \mathrm{L}^{-1}$, with the experimental data (Fig. $3 \mathrm{~b}$ ) adjusted to a second-degree polynomial regression model $\left(R^{2}>0.99\right)$.

Similarly, Roh et al. (2009) demonstrated that TCS at $2 \mathrm{mg}$ $\mathrm{L}^{-1}$ reduced nitrite production to $70 \%$ by using batch reactors with pure AOB cultures as biomass, and Dokianakis et al. (2004) showed that the same concentration of TCS inhibited enriched NOB. However, neither aforementioned study jointly considered AOB-NOB as a community. Furthermore, almost all available data on TCS toxicity from other studies have been obtained from activated sludge. Amariei et al. (2017) reported $\mathrm{EC}_{50}$ value of $0.32 \pm 0.07 \mathrm{mg} \mathrm{L}^{-1}$ with $125 \mathrm{mg}$ (TSS) $\mathrm{L}^{-1}$ via a respirometry assay, and via ammonia uptake rates (AUR), Stasinakis et al. (2008) estimated the $\mathrm{EC}_{50}$ value of $6.4 \mathrm{mg} \mathrm{L}^{-1}$ with $1100-1250 \mathrm{mg}$ (VSS) $\mathrm{L}^{-1}$.

Interestingly, all $\mathrm{EC}_{50}$ values obtained by the aforementioned studies were higher than the value obtained in the present work. These differences are attributed to the source and concentration of biomass used in the batch test, where lower biomass quantities could lead to lower toxicant tolerances. In this study, the biomass concentration was equivalent to $71 \pm$ $5 \mathrm{mg} \mathrm{VSS} \mathrm{L}{ }^{-1}$, lower than aforementioned studies. Amariei et al. (2017) demonstrated that the $\mathrm{EC}_{50}$ values increased by 17 -fold when increasing VSS from 125 to $1000 \mathrm{mg} \mathrm{L}^{-1}$. Nevertheless, TCS had a detrimental effect on nitrification, with a considerable activity reduction from 10 to $100 \mu \mathrm{g}$

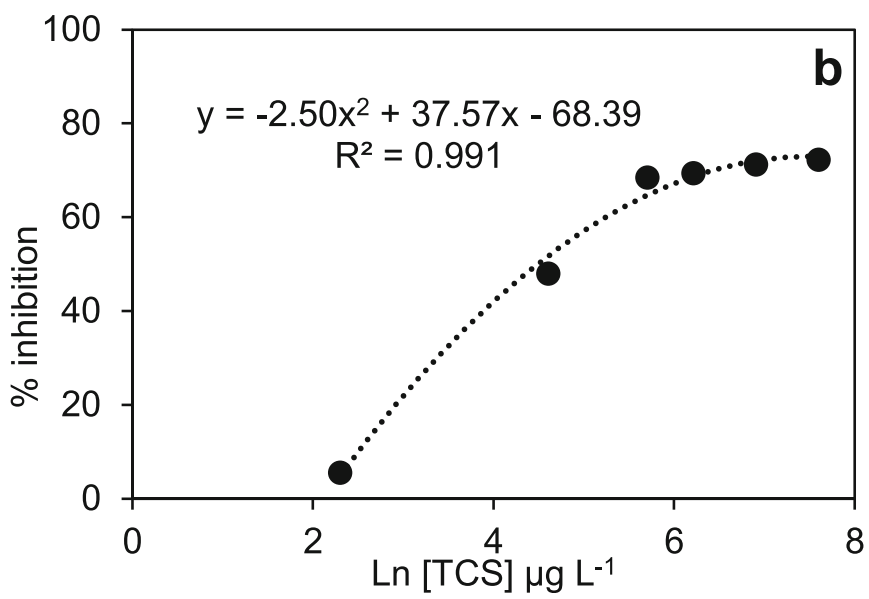


$\mathrm{L}^{-1}$. These results indicate that TCS may pose a risk on nitrifying bacteria under high peak loadings already reported in WWTPs (Kumar et al. 2010).

The impact of DEET on nitrification is shown in Fig. 4. DEET had a moderate effect on the nitrifying culture compared with the other PPCPs tested, with $38.7 \%$ inhibition at the highest concentration (10 $\mathrm{mg} \mathrm{L}^{-1}$ DEET). Limited information on the acute toxicity of DEET is available in the literature. Most studies have been carried out on aquatic organisms (Costanzo et al. 2007; Seo et al. 2005), which found lower toxicity $\left(\mathrm{EC}_{50}>100 \mathrm{mg} \mathrm{L}^{-1}\right)$ than the concentrations evaluated in the present work. Nevertheless, the batch test with DEET suggested that there is no significant toxicity (inhibition $<3 \%$ ) at environmental levels reported in the literature (Merel and Snyder 2016; Mohapatra et al. 2016).

Effects of antibiotics on nitrification activity

The \% inhibition results of AMP (ampicillin), OFX (ofloxacin) and CST (colistin) are presented in Fig. 5, along with the $\mathrm{EC}_{50}$ estimation plots. In general, all antibiotics had a detrimental effect on nitrification within the range of concentrations tested.

By analysing Fig. $5 \mathrm{~b}$, the $\mathrm{EC}_{50}$ value of $\mathrm{AMP}$ was calculated at $23.7 \mathrm{mg} \mathrm{L}^{-1}$, much lower than previous short-term studies with enriched nitrifying bacteria: $250 \mathrm{mg} \mathrm{L}^{-1}$ (Gomez et al. 1996) and $50 \mathrm{mg} \mathrm{L}^{-1}$ (Ramírez et al. 2020). The enhanced sensitivity of our assay can be attributed to lower biomass and degradation rates of AMP. Yu et al. (2019), with a long-term sequential batch reactor, demonstrated that $30 \mathrm{mg} \mathrm{L}^{-1}$ AMP had inhibited nitrification activity by 20 to $32 \%$. Moreover, in this study, activities of ammoniamonooxygenase and nitrite-oxidoreductase declined with the increase in AMP concentration, demonstrating that this antibiotic affects the AOB and NOB.

The plot of OFX \% inhibition against the logarithm of the concentration in Fig. $5 \mathrm{c}$ was adjusted to a linear regression model $\left(R^{2}>0.97\right)$, obtaining an $\mathrm{EC}_{50}$ value of $12.7 \mathrm{mg} \mathrm{L}^{-1}$ (Fig. 5d). As with DEET, limited data on the acute toxicity of

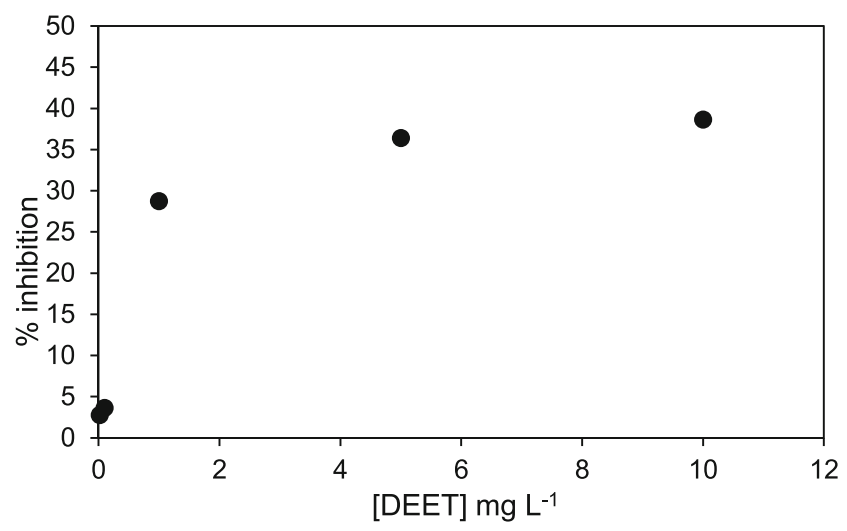

Fig. 4 Inhibition percentage at different concentrations of DEET. Maximum nitrification inhibition was below $40 \%$; thus, the regression plot was not performed for $\mathrm{EC}_{50}$ estimation
OFX to nitrifying bacteria is found in the literature, and with mixed results. Dorival-García et al. (2013) reported OFX had no inhibitory effect on nitrifying activated sludge at $500 \mu \mathrm{g}$ $\mathrm{L}^{-1}$. When reported, again, $\mathrm{EC}_{50}$ values in activated sludge were considerably higher, e.g. $165 \mathrm{mg} \mathrm{L}^{-1}$ (Tobajas et al. 2016). However, the $\mathrm{EC}_{50}$ value estimated in this study was within the range of OFX levels reported by Dokianakis et al. (2004) for enriched NOB culture: between 6 and $10 \mathrm{mg} \mathrm{L}^{-1}$.

Illustrated in Fig. 5f, 50\% inhibition by CST was $1 \mathrm{mg} \mathrm{L}^{-1}$. This estimation was about tenfold lower than the $\mathrm{EC}_{50}$ values reported by Bressan et al. (2013). The changes in the toxicity level may be due to the composition of the CST solution; here, CST sulphate salt (polymyxin E $\geq 15,000 \mathrm{IU} \mathrm{mg}^{-1}$; Sigma Aldrich) was used in the experiments. Bressan et al. (2013) tested two similar commercial CST formulations, one of which contained lactose as vehicle; they reported notable differences in mixed-microbial community tolerance between the two formulations $\left(\mathrm{EC}_{50}\right.$ of $67 \mathrm{mg} \mathrm{L}^{-1}$ for CST vs. $\mathrm{EC}_{50}$ of $10.8 \mathrm{mg} \mathrm{L}^{-1}$ for CST plus lactose), demonstrating that the composition of antibiotics could alter the response of the nitrifying bacteria.

Furthermore, Bressan et al. (2013) highlighted that nitrite oxidation was not affected by CST at their highest concentration $\left(316 \mathrm{mg} \mathrm{L}^{-1}\right)$, suggesting that the inhibitory effect of CST was more pronounced on AOB than on NOB. Given that NOB metabolism could be reduced due to lack of substrate availability, we spiked with $1000 \mathrm{mg} \mathrm{L}^{-1}$ sodium nitrite $\left(\mathrm{NaNO}_{2}\right)$ stock solution at the end of the incubation period to evaluate the response of NOB under the highest CST concentration $\left(350 \mathrm{mg} \mathrm{L}^{-1}\right)$ and corroborate the results reported by Bressan et al. (2013). The considerable reduction of nitrite levels $(\sim 98 \%)$ and the increase in nitrate levels to $93.8 \%$ demonstrated that CST had a low impact on NOB (Fig. 6). Moreover, the ammonium consumption remained low $(<5.5 \%)$, showing the persistent inhibition of CST on $\mathrm{AOB}$ metabolism.

In general, most of the PPCPs tested in this study had an impact on the performance of nitrifiers with the exception of $\mathrm{CF}$. The measurement of ammonium and oxidation products directly reflected the effects of each PPCP on AOB/NOB guilds compared to the control treatments. However, remarkable differences were observed with previous inhibition studies. Further research is required to determine how the concentration of nitrifying biomass can affect the toxicity tolerance against these contaminants. Additional experiments should be performed to evaluate other exposure scenarios, such as biomass acclimation, where the microbial communities could show higher capacity to withstand a wide range of chemicals and exhibit possible synergistic effects of PPCP mixtures on nitrification activity.

In summary, the inhibition capacity $\left(\mathrm{EC}_{50}\right)$ of TCS, AMP, OFX and CST in short exposure batch tests with nitrifying bacteria was $89.1 \mu \mathrm{g} \mathrm{L}^{-1}, 23.7 \mathrm{mg} \mathrm{L}^{-1}, 12.7 \mathrm{mg} \mathrm{L}^{-1}$ and $1 \mathrm{mg} \mathrm{L}^{-1}$, respectively. The maximum inhibition in the 

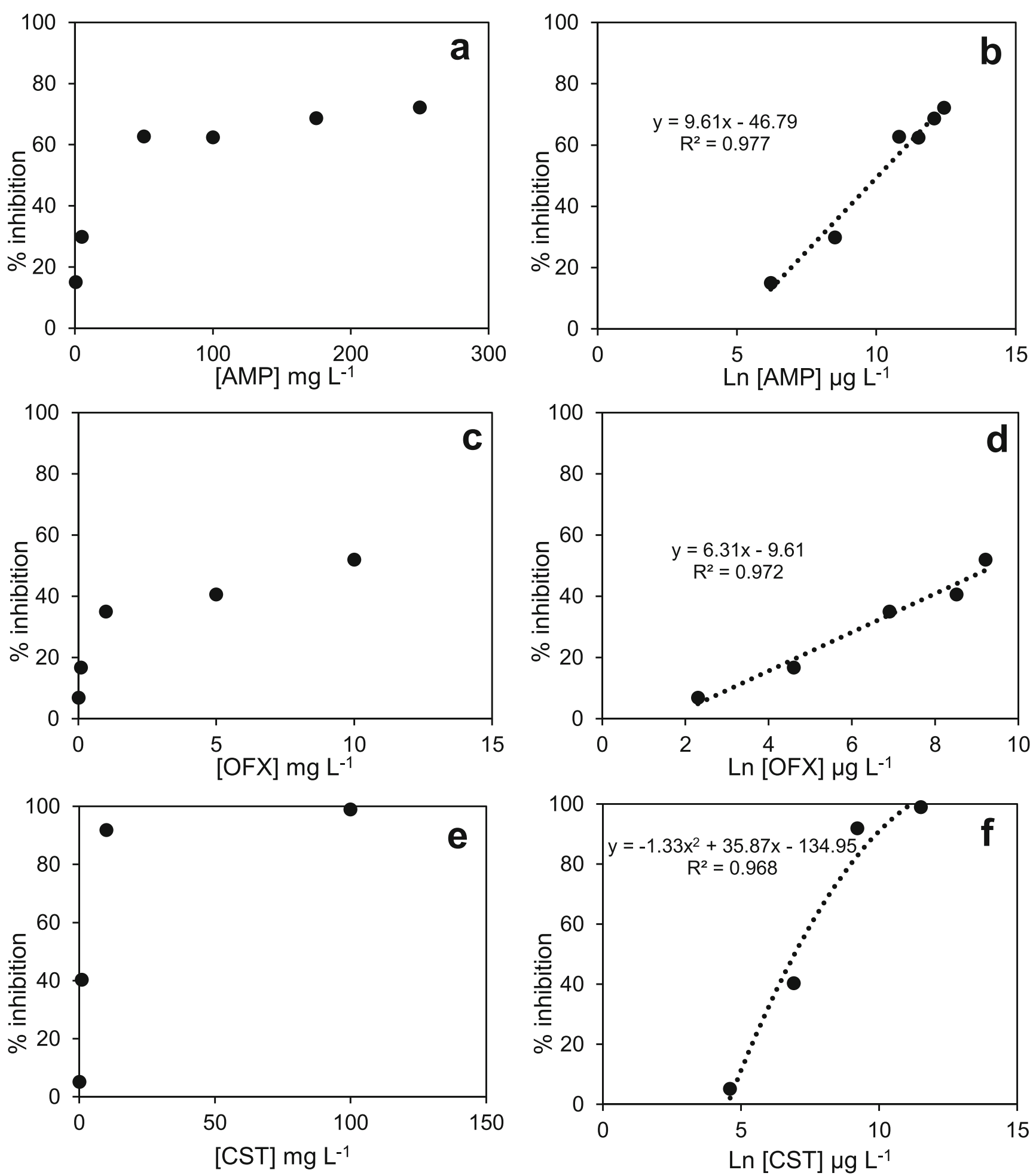

Fig. 5 Inhibition level at different antibiotic concentrations: $\mathbf{a}, \mathbf{b}$ ampicillin; $\mathbf{c}, \mathbf{d}$ ofloxacin; $\mathbf{e}, \mathbf{f}$ colistin

presence of DEET was close to $40 \%$ at $10 \mathrm{mg} \mathrm{L}^{-1}$, whereas no remarkable effect was observed for $\mathrm{CF}$ in concentrations up to $90 \mathrm{mg} \mathrm{L}^{-1}$. Among the PPCPs tested, TCS exhibited a more pronounced effect on nitrification activity at the concentrations above $0.01 \mathrm{mg} \mathrm{L}^{-1}$. Although the TCS levels reported in the environment are rarely near the $\mathrm{EC}_{50}$ values estimated in this study, this antimicrobial agent is commonly detected in WWTPs worldwide at higher concentrations compared to other PPCPs of concern (Tran et al. 2018). The data suggested that TCS is still widely consumed despite the efforts of governmental agencies to restrict its application in numerous household and personal care products (Bedoux et al. 2012). 


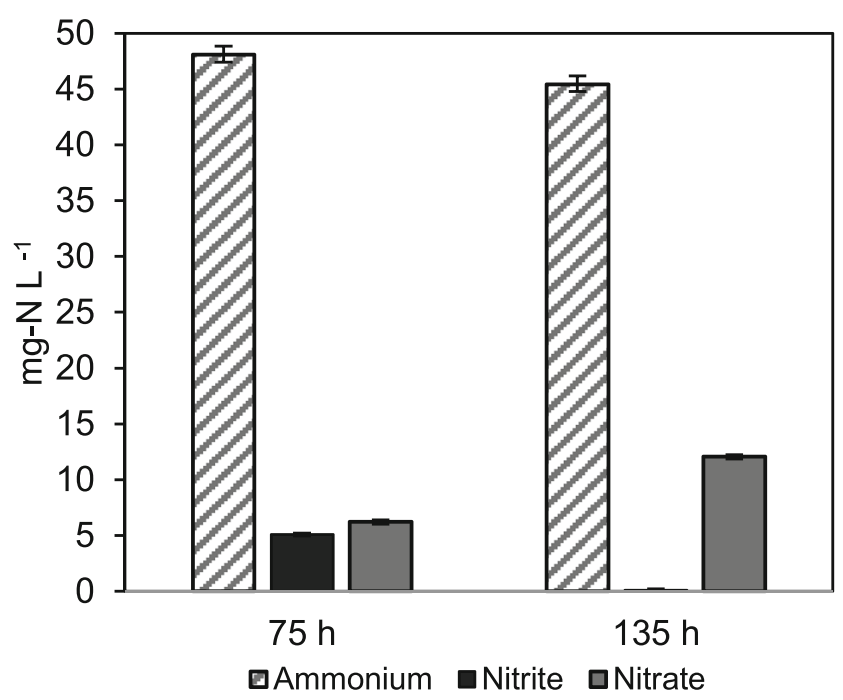

Fig. 6 Change of ammonium, nitrite and nitrate levels after the incubation period at concentration of $350 \mathrm{mg} \mathrm{L}^{-1}$ colistin

Therefore, TCS usage should be revised to control its excessive consumption and further disposal in the sewage that may lead to its accumulation at higher concentrations in the environment, thereby posing a risk to non-target microorganisms.

The results of acute toxicity analysis indicated that the levels of AMP and OFX detected in the environment were too low to inhibit nitrifier metabolism, considering that antibiotics often occur at concentrations from ng $\mathrm{L}^{-1}$ to $\mu \mathrm{g} \mathrm{\textrm {L } ^ { - 1 }}$ (Kümmerer 2009). Moreover, further research is necessary to investigate the occurrence and fate of CST in different habitats and evaluate the risks of CST concentrations in the environment.

\section{Conclusions}

The toxicity of the most common PPCPs was investigated using short-term nitrification inhibition assays. Based on the 16S rRNA gene sequencing and analysis, Nitrosomonas sp. belonging to AOB and Nitrobacter sp., a common NOB, were identified in the nitrifying biomass along with other microbial groups typically found in activated sludge. The experimental results of acute toxicity to enriched nitrifying bacteria obtained in this study suggested that the most toxic chemical was TCS compared to the other 5 PPCPs, showing the lowest $\mathrm{EC}_{50}$ value of $89.1 \mu \mathrm{g} \mathrm{L}^{-1}$. With regard to the antibiotics, CST exerted the highest toxicity to overall nitrification $\left(\mathrm{EC}_{50}\right.$ value of $1 \mathrm{mg} \mathrm{L}^{-1}$ ), with a more pronounced inhibition on AOB activity than on NOB activity. Results showed that the $\mathrm{EC}_{50}$ values estimated for AMP $\left(23.7 \mathrm{mg} \mathrm{L}^{-1}\right)$ and OFX $(12.7 \mathrm{mg}$ $\mathrm{L}^{-1}$ ) were considerably higher than environmentally relevant levels. CF had no remarkable inhibitory effects on nitrification performance. In the case of the insect repellent, DEET exerted partial inhibitory effects on nitrifying bacteria below $40 \%$ at the highest concentration $\left(10 \mathrm{mg} \mathrm{L}^{-1}\right)$.

Supplementary Information The online version contains supplementary material available at https://doi.org/10.1007/s11356-021-14696-7.

Acknowledgements The authors would like to thank Presley McGuire, Dr. Tanya Peshkur, Mara L. Knapp and Renee F. Knapp for their help with various aspects of the research project.

Author contribution Methodology, material preparation, laboratory experiments, data collection and analysis were performed by CL for all six toxicants. MN supported the laboratory experiments and data interpretation of the first three toxicants. CK and YFT contributed to the study's conception. The first draft of the manuscript was written by $\mathrm{CL}$ and all authors commented and edited on previous versions of the manuscript. All authors read and approved the final manuscript.

Funding This research was funded by the Research Grants Council of the Hong Kong SAR, China (No. 18202116) and PhD studentship for C.L. has been graciously provided by 'Engineering the Future' funds by the Faculty of Engineering, University of Strathclyde.

Availability of data and materials The datasets used and/or analysed during the current study are available from the corresponding author Dr. Charles W. Knapp (charles.knapp@strath.ac.uk) on reasonable request.

\section{Declarations}

Ethics approval and consent to participate Not applicable.

Consent for publication Not applicable.

Competing interests The authors declare no competing interests.

Open Access This article is licensed under a Creative Commons Attribution 4.0 International License, which permits use, sharing, adaptation, distribution and reproduction in any medium or format, as long as you give appropriate credit to the original author(s) and the source, provide a link to the Creative Commons licence, and indicate if changes were made. The images or other third party material in this article are included in the article's Creative Commons licence, unless indicated otherwise in a credit line to the material. If material is not included in the article's Creative Commons licence and your intended use is not permitted by statutory regulation or exceeds the permitted use, you will need to obtain permission directly from the copyright holder. To view a copy of this licence, visit http://creativecommons.org/licenses/by/4.0/.

\section{References}

Al Ali AA, Naddeo V, Hasan SW, Yousef AF (2020) Correlation between bacterial community structure and performance efficiency of a full-scale wastewater treatment plant. J Water Process Eng 37: 101472. https://doi.org/10.1016/j.jwpe.2020.101472 
Amariei G, Boltes K, Rosal R, Letón P (2017) Toxicological interactions of ibuprofen and triclosan on biological activity of activated sludge. J Hazard Mater 334:193-200. https://doi.org/10.1016/j.jhazmat. 2017.04.018

APHA (1998) Standard methods for the examination of water and wastewater, 20th edn. American Public Health Association, Washington

Armstrong DL, Lozano N, Rice CP et al (2019) Fate of triclosan, triclocarban, and their transformation products in wastewater under nitrifying conditions. J Water Process Eng 28:144-151. https://doi. org/10.1016/j.jwpe.2019.01.015

Aronson D, Weeks J, Meylan B et al (2012) Environmental release, environmental concentrations, and ecological risk of N,N-diethylm-toluamide (DEET). Integr Environ Assess Manag 8(1):135-166. https://doi.org/10.1002/ieam.271

Balakrishna K, Rath A, Praveenkumarreddy Y et al (2017) A review of the occurrence of pharmaceuticals and personal care products in Indian water bodies. Ecotoxicol Environ Saf 137:113-120. https:// doi.org/10.1016/j.ecoenv.2016.11.014

Bedoux G, Roig B, Thomas O et al (2012) Occurrence and toxicity of antimicrobial triclosan and by-products in the environment. Environ Sci Pollut Res 19(4):1044-1065. https://doi.org/10.1007/s11356011-0632-x

Bollmann A, French E, Laanbroek HJ (2011) Isolation, cultivation, and characterization of ammonia-oxidizing bacteria and archaea adapted to low ammonium concentrations. In: Methods in enzymology. Academic Press Inc., pp 55-88

Bolyen E, Rideout JR, Dillon MR et al (2019) Reproducible, interactive, scalable and extensible microbiome data science using QIIME 2. Nat Biotechnol 37:852-857. https://doi.org/10.1038/s41587-0190209-9

Brandt KK, Amézquita A, Backhaus T et al (2015) Ecotoxicological assessment of antibiotics: a call for improved consideration of microorganisms. Environ Int 85:189-205. https://doi.org/10.1016/j. envint.2015.09.013

Bressan CR, Kunz A, Schmidell W, Soares HM (2013) Toxicity of the colistin sulfate antibiotic used in animal farming to mixed cultures of nitrifying organisms. Water Air Soil Pollut 224:1441. https://doi. org/10.1007/s11270-013-1441-4

Brown KD, Kulis J, Thomson B et al (2006) Occurrence of antibiotics in hospital, residential, and dairy effluent, municipal wastewater, and the Rio Grande in New Mexico. Sci Total Environ 366:772-783. https://doi.org/10.1016/j.scitotenv.2005.10.007

BS ISO 15923-1 (2013) Water quality - determination of selected parameters by discrete analysis systems. Part 1: ammonium, nitrate, nitrite, chloride, orthophosphate, sulfate and silicate with photometric detection. The British Standards Institution. BSI Standards Limited.

BSI EN ISO 5667-3 (2018) Water quality - sampling. Part 3: preservation and handling of water samples. The British Standards Institution. BSI Standards Limited.

Chen M, Wang W, Feng Y et al (2014) Impact resistance of different factors on ammonia removal by heterotrophic nitrification-aerobic denitrification bacterium Aeromonas sp. HN-02. Bioresour Technol 167:456-461. https://doi.org/10.1016/j.biortech.2014.06.001

Costanzo SD, Watkinson AJ, Murby EJ et al (2007) Is there a risk associated with the insect repellent DEET (N,N-diethyl-m-toluamide) commonly found in aquatic environments? Sci Total Environ 384: 214-220. https://doi.org/10.1016/j.scitotenv.2007.05.036

Dagla I, Karkoula E, Baira E et al (2019) Analytical methodologies used for the determination of colistin in biological fluids. Is it still a challenge? J Pharm Biomed Anal 164:777-788. https://doi.org/10. 1016/j.jpba.2018.11.044

Dai G, Huang J, Chen W et al (2014) Major pharmaceuticals and personal care products (PPCPs) in wastewater treatment plant and receiving water in Beijing, China, and associated ecological risks. Bull
Environ Contam Toxicol 92:655-661. https://doi.org/10.1007/ s00128-014-1247-0

Dinh QT, Moreau-Guigon E, Labadie P et al (2017) Occurrence of antibiotics in rural catchments. Chemosphere 168:483-490. https://doi. org/10.1016/j.chemosphere.2016.10.106

Dokianakis SN, Kornaros ME, Lyberatos G (2004) On the effect of pharmaceuticals on bacterial nitrite oxidation. Water Sci Technol 50(5):341-346. https://doi.org/10.2166/wst.2004.0347

Dorival-García N, Zafra-Gómez A, Navalón A et al (2013) Removal and degradation characteristics of quinolone antibiotics in laboratoryscale activated sludge reactors under aerobic, nitrifying and anoxic conditions. J Environ Manag 120:75-83. https://doi.org/10.1016/j. jenvman.2013.02.007

Dsikowitzky L, Crawford SE, Nordhaus I et al (2020) Analysis and environmental risk assessment of priority and emerging organic pollutants in sediments from the tropical coastal megacity Jakarta, Indonesia. Reg Stud Mar Sci 34:101021. https://doi.org/10.1016/j. rsma.2019.101021

Gheorghe S, Petre J, Lucaciu I et al (2016) Risk screening of pharmaceutical compounds in Romanian aquatic environment. Environ Monit Assess 188(6):1-16. https://doi.org/10.1007/s10661-016-5375-3

Gomez J, Mendez R, Lema JM (1996) The effect of antibiotics on nitrification processes batch assays. Appl Biochem Biotechnol - Part A Enzym Eng Biotechnol 36(2):21. https://doi.org/10.1007/ BF02941767

Graham DW, Knapp CW, Van Vleck ES et al (2007) Experimental demonstration of chaotic instability in biological nitrification. ISME J 1(5):385-393. https://doi.org/10.1038/ismej.2007.45

Grunditz C, Dalhammar G (2001) Development of nitrification inhibition assays using pure cultures of Nitrosomonas and Nitrobacter. Water Res 35(2):433-440. https://doi.org/10.1016/S0043-1354(00)003122

Gwak JH, Jung MY, Hong H et al (2020) Archaeal nitrification is constrained by copper complexation with organic matter in municipal wastewater treatment plants. ISME J 14:335-346. https://doi. org/10.1038/s41396-019-0538-1

He Y, Langenhoff AAM, Comans RNJ et al (2018) Effects of dissolved organic matter and nitrification on biodegradation of pharmaceuticals in aerobic enrichment cultures. Sci Total Environ 630:13351342. https://doi.org/10.1016/j.scitotenv.2018.02.180

Hembach N, Schmid F, Alexander J et al (2017) Occurrence of the mcr-1 colistin resistance gene and other clinically relevant antibiotic resistance genes in microbial populations at different municipal wastewater treatment plants in Germany. Front Microbiol 8:1282. https:// doi.org/10.3389/fmicb.2017.01282

ISO-9509 (2006) Water Quality-Toxicity test for assessing the inhibition of nitrification of activated sludge microorganisms. Int Organ Standard.

Jeong D, Bae H (2021) Insight into functionally active bacteria in nitrification following $\mathrm{Na}^{+}$and $\mathrm{Mg}^{2+}$ exposure based on 16S rDNA and 16S rRNA sequencing. Sci Total Environ 758:143592. https://doi. org/10.1016/j.scitotenv.2020.143592

Johnston J, LaPara T, Behrens S (2019) Composition and dynamics of the activated sludge microbiome during seasonal nitrification failure. Sci Rep 9:4565. https://doi.org/10.1038/s41598-019-40872-4

Juksu K, Zhao JL, Liu YS et al (2019) Occurrence, fate and risk assessment of biocides in wastewater treatment plants and aquatic environments in Thailand. Sci Total Environ 690(10):1110-1119. https://doi.org/10.1016/j.scitotenv.2019.07.097

Kapoor V, Li X, Chandran K et al (2016) Use of functional gene expression and respirometry to study wastewater nitrification activity after exposure to low doses of copper. Environ Sci Pollut Res 23(7): 6443-6450. https://doi.org/10.1007/s11356-015-5843-2

Kemper N (2008) Veterinary antibiotics in the aquatic and terrestrial environment. Ecol Indic 8:1-13. https://doi.org/10.1016/j.ecolind. 2007.06.002 
Kempf I, Jouy E, Chauvin C (2016) Colistin use and colistin resistance in bacteria from animals. Int J Antimicrob Agents 48:598-606. https:// doi.org/10.1016/j.ijantimicag.2016.09.016

King DE, Malone R, Lilley SH (2000) New classification and update on the quinolone antibiotics. Am Fam Physician 61(9):2741-2748

Knapp CW, Graham DW (2007) Nitrite-oxidizing bacteria guild ecology associated with nitrification failure in a continuous-flow reactor. FEMS Microbiol Ecol 62(2):195-201. https://doi.org/10.1111/j. 1574-6941.2007.00380.x

Kong Q, He X, Feng Y et al (2017) Pollutant removal and microorganism evolution of activated sludge under ofloxacin selection pressure. Bioresour Technol 241:849-856. https://doi.org/10.1016/j. biortech.2017.06.019

Koops HP, Pommerening-Röser A (2001) Distribution and ecophysiology of the nitrifying bacteria emphasizing cultured species. FEMS Microbiol Ecol 37:1-9. https://doi.org/10.1016/S0168-6496(01) 00137-4

Kumar KS, Priya SM, Peck AM, Sajwan KS (2010) Mass loadings of triclosan and triclocarban from four wastewater treatment plants to three rivers and landfill in Savannah, Georgia, USA. Arch Environ Contam Toxicol 58:275-285. https://doi.org/10.1007/s00244-0099383-y

Kümmerer K (2009) The presence of pharmaceuticals in the environment due to human use - present knowledge and future challenges. J Environ Manag 90:2354-2366. https://doi.org/10.1016/j.jenvman. 2009.01.023

Kwon G, Kim H, Song C, Jahng D (2019) Co-culture of microalgae and enriched nitrifying bacteria for energy-efficient nitrification. Biochem Eng J 152:107385. https://doi.org/10.1016/j.bej.2019. 107385

Lakshminarasimman N, Quiñones O, Vanderford BJ et al (2018) Biotransformation and sorption of trace organic compounds in biological nutrient removal treatment systems. Sci Total Environ 640641:62-72. https://doi.org/10.1016/j.scitotenv.2018.05.145

Lehutso RF, Daso AP, Okonkwo JO (2017) Occurrence and environmental levels of triclosan and triclocarban in selected wastewater treatment plants in Gauteng Province, South Africa. Emerg Contam 3: 107-114. https://doi.org/10.1016/j.emcon.2017.07.001

Leung HW, Minh TB, Murphy MB et al (2012) Distribution, fate and risk assessment of antibiotics in sewage treatment plants in Hong Kong, South China. Environ Int 42:1-9. https://doi.org/10.1016/j.envint. 2011.03.004

Li J, Milne RW, Nation RL et al (2003) Stability of colistin and colistin methanesulfonate in aqueous media and plasma as determined by high-performance liquid chromatography. Antimicrob Agents Chemother 47:1364-1370. https://doi.org/10.1128/AAC.47.4. 1364-1370.2003

Li X, Kapoor V, Impelliteri C et al (2016) Measuring nitrification inhibition by metals in wastewater treatment systems: current state of science and fundamental research needs. Crit Rev Environ Sci Technol 46(3):249-289. https://doi.org/10.1080/10643389.2015. 1085234

Li S, Ma B, She Z et al (2020) Effect of norfloxacin on performance, microbial enzymatic activity and microbial community of a sequencing batch reactor. Environ Technol Innov 18:100726. https:// doi.org/10.1016/j.eti.2020.100726

Liu JL, Wong MH (2013) Pharmaceuticals and personal care products (PPCPs): a review on environmental contamination in China. Environ Int 59:208-224. https://doi.org/10.1016/j.envint.2013.06. 012

Liu YY, Wang Y, Walsh TR et al (2016) Emergence of plasmid-mediated colistin resistance mechanism MCR-1 in animals and human beings in China: a microbiological and molecular biological study. Lancet Infect Dis 16:161-168. https://doi.org/10.1016/S1473-3099(15) 00424-7
Luo Y, Guo W, Ngo HH et al (2014) A review on the occurrence of micropollutants in the aquatic environment and their fate and removal during wastewater treatment. Sci Total Environ 473-474:619641. https://doi.org/10.1016/j.scitotenv.2013.12.065

Maidak BL, Cole JR, Lilburn TG, Parker CT, Saxman PR, Farris RJ, Garrity GM, Olsen GJ, Schmidt TM, Tiedje JM (2001) The RDPII (Ribosomal Database Project). Nucleic Acids Res. 29:173-174

Marx C, Mühlbauer V, Schubert S et al (2015) Representative input load of antibiotics to WWTPs: predictive accuracy and determination of a required sampling quantity. Water Res 76:19-32. https://doi.org/10. 1016/j.watres.2015.02.049

Merel S, Snyder SA (2016) Critical assessment of the ubiquitous occurrence and fate of the insect repellent N,N-diethyl-m-toluamide in water. Environ Int 96:98-117. https://doi.org/10.1016/j.envint. 2016.09.004

Minh TB, Leung HW, Loi IH et al (2009) Antibiotics in the Hong Kong metropolitan area: ubiquitous distribution and fate in Victoria Harbour. Mar Pollut Bull 58:1052-1062. https://doi.org/10.1016/j. marpolbul.2009.02.004

Mitchell SM, Ullman JL, Teel AL, Watts RJ (2014) PH and temperature effects on the hydrolysis of three $\beta$-lactam antibiotics: ampicillin, cefalotin and cefoxitin. Sci Total Environ 466-467:547-555. https:// doi.org/10.1016/j.scitotenv.2013.06.027

Mohapatra S, Huang CH, Mukherji S, Padhye LP (2016) Occurrence and fate of pharmaceuticals in WWTPs in India and comparison with a similar study in the United States. Chemosphere 159:526-535. https://doi.org/10.1016/j.chemosphere.2016.06.047

Moussa MS, Lubberding HJ, Hooijmans CM et al (2003) Improved method for determination of ammonia and nitrite oxidation activities in mixed bacterial cultures. Appl Microbiol Biotechnol 63:217-221. https://doi.org/10.1007/s00253-003-1360-1

Mutiyar PK, Mittal AK (2014) Occurrences and fate of selected human antibiotics in influents and effluents of sewage treatment plant and effluent-receiving river Yamuna in Delhi (India). Environ Monit Assess 186:541-557. https://doi.org/10.1007/s10661-013-3398-6

Nogueira R, Melo LF (2006) Competition between Nitrospira spp. and Nitrobacter spp. in nitrite-oxidizing bioreactors. Biotechnol Bioeng 95:169-175. https://doi.org/10.1002/bit.21004

Nowka B, Daims H, Spieck E (2015) Comparison of oxidation kinetics of nitrite-oxidizing bacteria: nitrite availability as a key factor in niche differentiation. Appl Environ Microbiol 81:745-753. https://doi. org/10.1128/AEM.02734-14

Paíga P, Correia M, Fernandes MJ et al (2019) Assessment of 83 pharmaceuticals in WWTP influent and effluent samples by UHPLCMS/MS: hourly variation. Sci Total Environ 648:582-600. https:// doi.org/10.1016/j.scitotenv.2018.08.129

Pasquini L, Merlin C, Hassenboehler L et al (2013) Impact of certain household micropollutants on bacterial behavior. Toxicity tests/ study of extracellular polymeric substances in sludge. Sci Total Environ 463-464:355-365. https://doi.org/10.1016/j.scitotenv. 2013.06.018

Peng Y, Zhu G (2006) Biological nitrogen removal with nitrification and denitrification via nitrite pathway. Appl Microbiol Biotechnol 73(1): 15-26. https://doi.org/10.1007/s00253-006-0534-z

Quadra GR, Paranaíba JR, Vilas-Boas J et al (2020) A global trend of caffeine consumption over time and related-environmental impacts. Environ Pollut 256:113343. https://doi.org/10.1016/j.envpol.2019. 113343

Radniecki TS, Lauchnor EG (2011) Investigating Nitrosomonas europaea stress biomarkers in batch, continuous culture, and biofilm reactors. In: Methods in enzymology. pp 217-246

Ramaswamy BR, Shanmugam G, Velu G et al (2011) GC-MS analysis and ecotoxicological risk assessment of triclosan, carbamazepine and parabens in Indian rivers. J Hazard Mater 186:1586-1593. https://doi.org/10.1016/j.jhazmat.2010.12.037 
Ramírez Muñoz JJ, de Cuervo López MF, Texier AC (2020) Ampicillin biotransformation by a nitrifying consortium. World J Microbiol Biotechnol 36(2):21. https://doi.org/10.1007/s11274-020-2798-3

Robertson J, Iwamoto K, Hoxha I et al (2019) Antimicrobial medicines consumption in Eastern Europe and Central Asia - an updated crossnational study and assessment of quantitative metrics for policy action. Front Pharmacol 9:1156. https://doi.org/10.3389/fphar. 2018.01156

Roh H, Subramanya N, Zhao F et al (2009) Biodegradation potential of wastewater micropollutants by ammonia-oxidizing bacteria. Chemosphere 77:1084-1089. https://doi.org/10.1016/j. chemosphere.2009.08.049

Salem S, Moussa MS, Van Loosdrecht MCM (2006) Determination of the decay rate of nitrifying bacteria. Biotechnol Bioeng 94(2):252262. https://doi.org/10.1002/bit.20822

Schmidt EL, Belser LW (1994) Autotrophic nitrifying bacteria. In: R. W. Weaver, Scott Angle, Peter Bottomley, David Bezdicek, Scott Smith, Ali Tabatabai AW (ed) Methods of soil analysis: Part 2 Microbiological and biochemical properties, 5.2. Soil Science Society of America, Inc., pp 159-177

Seo J, Lee YG, Kim SD et al (2005) Biodegradation of the insecticide N, $\mathrm{N}$-diethyl-m-toluamide by fungi: identification and toxicity of metabolites. Arch Environ Contam Toxicol 48(3):323-328. https://doi. org/10.1007/s00244-004-0029-9

Song X, Turiel E, He L, Martín-Esteban A (2020) Synthesis of molecularly imprinted polymers for the selective extraction of polymyxins from environmental water samples. Polymers (Basel) 12(1):131. https://doi.org/10.3390/polym12010131

Stadler LB, Love NG (2016) Impact of microbial physiology and microbial community structure on pharmaceutical fate driven by dissolved oxygen concentration in nitrifying bioreactors. Water Res 104:189 199. https://doi.org/10.1016/j.watres.2016.08.001

Stasinakis AS, Mamais D, Thomaidis NS et al (2008) Inhibitory effect of triclosan and nonylphenol on respiration rates and ammonia removal in activated sludge systems. Ecotoxicol Environ Saf 70:199-206. https://doi.org/10.1016/j.ecoenv.2007.12.011

Sui Q, Huang J, Deng S et al (2010) Occurrence and removal of pharmaceuticals, caffeine and DEET in wastewater treatment plants of Beijing, China. Water Res 44:417-426. https://doi.org/10.1016/j. watres.2009.07.010

Tobajas M, Verdugo V, Polo AM et al (2016) Assessment of toxicity and biodegradability on activated sludge of priority and emerging pollutants. Environ Technol 37(6):713-721. https://doi.org/10.1080/ 09593330.2015 .1079264

Tran NH, Li J, Hu J, Ong SL (2014) Occurrence and suitability of pharmaceuticals and personal care products as molecular markers for raw wastewater contamination in surface water and groundwater. Environ Sci Pollut Res 21:4727-4740. https://doi.org/10.1007/ s11356-013-2428-9

Tran NH, Chen H, Reinhard M et al (2016) Occurrence and removal of multiple classes of antibiotics and antimicrobial agents in biological wastewater treatment processes. Water Res 104:461-472. https:// doi.org/10.1016/j.watres.2016.08.040

Tran NH, Reinhard M, Gin KYH (2018) Occurrence and fate of emerging contaminants in municipal wastewater treatment plants from different geographical regions-a review. Water Res 133:182-207. https://doi.org/10.1016/j.watres.2017.12.029

Wang B, Ni BJ, Yuan Z, Guo J (2019) Cometabolic biodegradation of cephalexin by enriched nitrifying sludge: process characteristics, gene expression and product biotoxicity. Sci Total Environ. https://doi.org/10.1016/j.scitotenv.2019.03.473

Watkinson AJ, Murby EJ, Costanzo SD (2007) Removal of antibiotics in conventional and advanced wastewater treatment: implications for environmental discharge and wastewater recycling. Water Res 41: 4164 4176. https://doi.org/10.1016/j.watres.2007.04.005

Weeks JA, Guiney PD, Nikiforovz AI (2012) Assessment of the environmental fate and ecotoxicity of N,N-diethyl-m-toluamide (DEET). Integr Environ Assess Manag 8:120-134. https://doi.org/10.1002/ ieam. 1246

Xiao Y, De Araujo C, Sze CC, Stuckey DC (2015) Toxicity measurement in biological wastewater treatment processes: a review. J Hazard Mater 286:15-29. https://doi.org/10.1016/j.jhazmat.2014.12.033

Yang Y, Ok YS, Kim K-H, Kwon EE, Tsang YF (2017) Occurrences and removal of pharmaceuticals and personal care products (PPCPs) in drinking water and water/sewage treatment plants: A review. Sci Total Environ 596-597:303-320

Yao R, Yang H, Yu M et al (2016) Enrichment of nitrifying bacteria and microbial diversity analysis by high-throughput sequencing. RSC Adv 6:113959-113966. https://doi.org/10.1039/C6RA24213H

Ye L, Shao MF, Zhang T et al (2011) Analysis of the bacterial community in a laboratory-scale nitrification reactor and a wastewater treatment plant by 454-pyrosequencing. Water Res 45:4390-4398. https://doi. org/10.1016/j.watres.2011.05.028

$\mathrm{Yu}$ N, Zhao C, Ma B et al (2019) Impact of ampicillin on the nitrogen removal, microbial community and enzymatic activity of activated sludge. Bioresour Technol 272:337-345. https://doi.org/10.1016/j. biortech.2018.10.048

Yuan Y, Yu Y, Xi H et al (2019) Comparison of four test methods for toxicity evaluation of typical toxicants in petrochemical wastewater on activated sludge. Sci Total Environ 685:273-279. https://doi.org/ 10.1016/j.scitotenv.2019.05.389

Zhang L, Shen Z, Fang W, Gao G (2019) Composition of bacterial communities in municipal wastewater treatment plant. Sci Total Environ 689:1181-1191. https://doi.org/10.1016/j.scitotenv.2019.06.432

Zhang D, Gao J, Zhang L et al (2020) Responses of nitrification performance, triclosan resistome and diversity of microbes to continuous triclosan stress in activated sludge system. J Environ Sci (China) 92: 211-223. https://doi.org/10.1016/j.jes.2020.02.023

Zhao JL, Ying GG, Liu YS et al (2010) Occurrence and risks of triclosan and triclocarban in the Pearl River system, South China: from source to the receiving environment. J Hazard Mater 179:215-222. https:// doi.org/10.1016/j.jhazmat.2010.02.082

Zheng G, Yu B, Wang Y et al (2020) Removal of triclosan during wastewater treatment process and sewage sludge composting - a case study in the middle reaches of the Yellow River. Environ Int 134: 105300. https://doi.org/10.1016/j.envint.2019.105300

Publisher's note Springer Nature remains neutral with regard to jurisdictional claims in published maps and institutional affiliations. 